\title{
TANTANGAN GURU ABAD 21 DALAM MENGAJARKAN MUATAN SBdP DI SEKOLAH DASAR
}

\author{
Ade Saputro ${ }^{1^{*}}$ \\ Okto Wijayanti ${ }^{2}$ \\ ${ }^{1,2}$ Universitas Muhammadiyah Purwokerto, Purwokerto, Indonesia \\ adesaputro474@gmail.com ${ }^{1 *}$ \\ wijayantiokto@gmail.com ${ }^{2}$
}

\begin{abstract}
Abstrak
Penelitian ini bertujuan untuk mengetahui tantangan, hambatan dan kinerja guru dalam mengajarkan muatan SBdP di sekolah dasar. Penelitian ini merupakan penelitian kualitatif dengan metode penelitian deskriptif dengan subjek enam kepala sekolah dan dua belas guru yang ada di wilayah kecamatan kembaran. Teknik pengumpulan data menggunakan wawancara, observasi, dan analisis dokumen. Hasil penelitian menunjukan bahwa pelaksanaan pembelajaran SBdP kurikulum 2013 di SD mengalami banyak kendala dan tantangan, beberapaa diantaranya yaitu muatan materi yang terlalu sedikit yang terdapat didalam modul sehingga guru harus mencari reverensi dari sumber lain untuk melengkapi materi, materi dianggap terlalu tinggi untuk anak SD sehingga selain guru yang kesulitan dalam menyampaikan materi siswapun kesulitan dalam menerimanya, guru terkendala ketika praktik karena memang rata - rata guru tidak mempunyai basic dibidang seni atau guru tidak disiapkan untuk menjadi guru yang menguasai seni, dan guru juga sering terkendala dalam hal media karena kebanyakan sekolah belum menyediakan sarana dan prasarana serta media yang memadai untuk mendukung proses pembelajaran. Faktor yang mempengaruhi kinerja guru dalam mengajarkan muatan pelajaran SBdP di SD wilayah kecamatan kembaran yaitu guru dengan latar belakang pendidikan S1 PGSD mempunyai kinerja yang lebih baik dibandingkan dengan guru dengan latar belakang pendidikan PGSD UT hal tersebut dikarenakan guru lulusan S1 PGSD sudah mendapat bekal berupa mata kuliah konsep dasar seni baik itu seni rupa, musik dan tari, usia guru, guru dengan usia yang lebih muda cenderung mempunyai kinerja yang lebih baik dibandingkan dengan guru yang sudah senior hal tersebut karena guru dengan usia yang lebih muda mempunyai semangat yang besar dan lebih kreatif dalam mengajar dan dari status kepegawaian guru tersebut, guru dengan status PNS mempunyai kinerja yang lebih baik dibandingkan dengan guru dengan status belum PNS. Upaya untuk meningkatkan kinerja guru agar lebih baik yaitu dengan mencari tambahan materi dari reverensi lain, berdiskusi dengan guru yang mempunyai basic dibidang seni, dukungan penuh dari kepala sekolah baik secara moral ataupun teori dalam pembelajaran seni dan keikutsertaan pada pelatihan seni yang bekelanjutan agar tercapainya tujuan pembelajaran SBdP.
\end{abstract}

Kata Kunci: Pembelajaran SBdP, Tantangan kinerja guru, Guru abad 21, Kurikulum 2013

Published by:

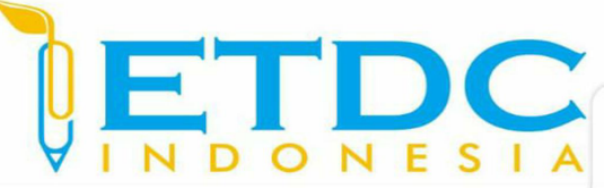

Copyright (C) 2021 The Author (s)

This article is licensed under CC BY 4.0 License

(cc) $\mathrm{BY}$ 


\section{TANTANGAN GURU ABAD 21 DALAM MENGAJARKAN MUATAN SBdP DI SEKOLAH DASAR}

\section{Pendahuluan}

Pendidikan merupakan bagian terpenting dari seluruh aspek kehidupan, baik untuk kehidupan sosial maupun kehidupan pribadi. Melalui pendidikan, setiap individu dapat mengembangkan kemampuan intelektual dan membentuk karakter yang baik untuk meningkatkan sumber daya manusia dalam kehidupan berbangsa dan bernegara. Karakter bangsa merupakan aspek yang penting dari kualitas sumber daya manusia yang menentukan kemajuan suatu bangsa.

Pendidikan adalah usaha membina dan mengembangkan kepribadian manusia baik dibagian rohani atau dibagian jasmani. Ada juga para beberapa orang ahli mengartikan pendidikan itu adalah suatu proses pengubahan sikap dan tingkah laku seseorang atau sekelompok orang dalam mendewasakan melalui pengajaran dan latihan. Dengan pendidikan kita bisa lebih dewasa karena pendidikan tersebut memberikan dampak yang sangat positif bagi kita, dan juga pendidikan tersebut bisa memberantas buta huruf dan akan memberikan keterampilan, kemampuan mental, dan lain sebagainya. Seperti yang tertera di dalam UU No.20 tahun 2003 Pendidikan adalah usaha dasar dan terencana untuk mewujudkan suasana belajar dan proses pembelajaran agar peserta didik secara aktif mengembangkan potensi dirinya untuk memiliki kekuatan spiritual keagamaan, pengendalian diri, kepribadian, kecerdasan, akhlak mulia, serta keterampilan, yang diperlukan dirinya, masyarakat, dan Negara.

Seiring perkembangan zaman, persoalan guru memang sangat kompleks. Terlebih menjadi guru di abad 21 sangat berbeda dengan guru di abad 20-an, kini eksistensi guru tidak lagi dilihat dari kharismanya semata. Karim dan Saleh Sugiyanto (2006). Lebih dari itu, sekarang dituntut bagaimana upaya seorang guru mampu berkomunikasi dan beradaptasi mengikuti arah tangan zaman. Guru di era digital haruslah mampu berinovasi dan berkreasi, karena sistem pembelajaran tahun 80-an sudah tidak diterima oleh anak didik zaman sekarang.

Salah satu dimensi yang tidak bisa dipisahkan dari pembangunan dunia pendidikan nasional di masa depan adalah kebijakan mengenai kurikulum. Kurikulum merupakan jantungnya dunia pendidikan. Untuk itu, kurikulum dimasa depan perlu dirancang dan disempurnakan untuk meningkatkan mutu pendidikan secara nasional dan meningkatkan mutu sumber daya manusia Indonesia (Puskur, 2007). Kurikulum merupakan seperangkat rencana dan pengaturan mengenai tujuan, isi, dan bahan pelajaran serta cara yang digunakan sebagai pedoman penyelenggaraan kegiatan pembelajaran untuk mencapai tujuan pendidikan nasional 
(UU No.20 Tahun 2003). Kurikulum 2013 pada dasarnya merupakan upaya penyederhanaan dan tematik-integratif yang disiapkan untuk mencetak generasi yang siap di dalam menghadapi masa depan. Karena itu, kurikulum disusun untuk mengantisipasi perkembangan masa depan. Titik beratnya, bertujuan untuk mendorong peserta didik atau siswa, mampu lebih baik dalam melakukan keterampilan proses.

Dalam penerapannya gurulah yang nantinya akan merasakan sendiri secara langsung dampak dari penerapan kurikulum tersebut, untuk mengelola pembelajaran, guru perlu memahami karakteristik siswa serta cara menerapkannya dengan baik. Di dalamnya meliputi kemampuan guru dalam memahami peserta didik, perencanaan dan pelaksaaan pembelajaran, evaluasi hasil belajar dan lainnya. Selain itu guru juga harus mampu menyampaikan semua materi pelajaran dengan sebaik mungkin apalagi dalam kurikulum 2013 ini pembelajarannya berdasarkan sistem tematik, yaitu semua mata pelajaran dijadikan dalam satu tema, termasuk pelajaran seni dan budaya. Mata pelajaran SBDP diberikan di sekolah karena keunikan, kebermaknaan, dan kebermanfaatan terhadap kebutuhan perkembangan peserta didik, yang terletak pada pemberian pengalaman estetik dalam bentuk kegiatan berekspresi/berkreasi dan berapresiasi melalui pendekatan: "belajar dengan seni," "belajar melalui seni" dan "belajar tentang seni." Peran ini hanya dapat diberikan melalui mata pelajaran seni. Pentingnya seni dalam pendidikan, disampaikan oleh Ki Hajar Dewantara "Seni adalah segala sesuatu perbuatan manusia yang timbul dari hidup perasaannya dan bersifat indah, sehingga dapat menggerakan jiwa perasaan manusia” (Hadjar Primadi, 2009). Seni menurut pandangan Ki Hajar Dewantara, diyakini dapat menggerakan jiwa perasaan manusia sehingga sangat dibutuhkan dalam membentuk kepribadian peserta didik sehingga diharapkan menjadi manusia yang memiliki kepribadian yang utuh (berkarakter) di kemudian hari. Dalam pelaksanaan pembelajaran SBdP Tematik Terpadu Kurikulum 2013 guru harus mengetahui bagaimana cara mengajarkan materi sesuai dengan Kurikulum 2013 yang berlaku. Maka penulis ingin mengkaji mengenai tantangan guru dalam mengajarkan SBdP Tematik Terpadu Kurikulum 2013 Kurikulum 2013 dalam proses belajar mengajar pada Sekolah Dasar di Kecamatan kembaran.

\section{Metode Penelitian}

Penelitian ini merupakan jenis penelitian Kualitatif dengan metode penelitian deskriptif dengan subjek penelitian kepala sekolah, 6 guru kelas rendah, dan 6 guru kelas tinggi. Penelitian ini dilakukan di SD wilayah Kecamatan Kembaran Banyumas. Teknik pengumpulan data dilakukan dengan cara wawancara, observasi dan dokumentasi. Peneliti berperan sebagai pewawancara langsung untuk menggali data melalui kepala sekolah dan guru kelas. Langkah - 
langkah yang dilakukan peneliti yaitu mengumpulkan data, reduksi data, dan menyimpulkan data.

\section{Hasil dan Pembahasan}

\subsection{Tantangan Guru dalam Mengajarkan Muatan SBdP}

Seni budaya dan prakarya (SBdP) merupakan salah satu muatan pelajaran yang terdapat dalam pembelalajaran tematik sekolah dasar. Kelompok mata pelajaran estetika bertujuan untuk memberikan pengalaman estetis kepada peserta didik yang berbentuk sikap apresiatif dan ekspresif. Hal tersebut sesuai dgan PermendikbudNomor 21 tahun 2016 tentang Standar Isi Pendidikan Dasar dan Menengah yang menyebutkankompetensi dari pembelaajaran Seni Rupa dan Prakarya (SBdP) adalah menunjukan perilaku rasa ingin tahu, peduli lingkungan, kerjasama, jujur, percaya diri dan mandiri dalam berkarya seni budaya dan prakarya, mengenal keragaman karaya seni budaya dan prakarya, memiliki kepekaan indrawi terhadap karya seni rupa budaya dan prakarya, menciptakan secara orisinil karya seni rupa budaya dan prakarya, serta menciptakan secara tiruan/rekreatif karya seni seni budaya dan prakarya.

Dalam mengajarkan materi seni budaya dan prakarya tentunya guru tidak akan semudah itu, terdapat beberapa tantangan yang guru harus hadapi ketika mengajarkan materi SBdP tersebut apalagi muatan Seni budaya dan prakarya erat kaitannya dengan kegiatan seni yang berhubungan dengan praktik. Tantangan itu sendiri mempunayai arti suatu hal atau bentuk usaha yang memiliki tujuan untuk menggugah kemampuan. Teantunya dalam penyampaian materi guru seringkali menemui tantangan dan hambatan ketikan mengajarkan mutan seni budaya dan prakarya tematik kurikulum 2013 khususnya yang ada di lingkup wilayah Kecamatan Kembaran yang tepatnya berlokasi di SDN Tambaksari, SD UMP, SDN Kembabran, SDN Linggasari 2, SDN Pliken 1 dan SDN Pliken 2.

Berdasarkan hasil wawancara dengan guru dan kepala sekolah dapat ditarik kesimpulan bahwa kinerja guru dalam mengajarkan muatan SBdP masih belum terlalu maksimal hal ini terbukti dengan ditemukannya banyak tantantangan yang dihadapi oleh guru pada saat mengajarakan materi SBdP beberapa tantangangan dan kesulitan yang sering dihadapi oleh guru yaitu dari segi materi, materi yang terdapat didalam modul masih terlalu sedikit dan itupun hanya garis besarnya saja sehingga guru masih harus mencari materi tambahan dari reverensi lain. Selain itu guru masih kesulitan dalam menyampaikan karena gurupun harus belajaar terlebih dahulu tentang materi yang akan disampaikan karena memang rata - rata guru tidak mempunyai basic dan kemampuan di bidang seni sehingga gurupun harus mulai belajr dari nol kembali dan seringkali guru terkendala pada saat melaksanakan praktik guru kerap kali 
menemui kesulitan saat praktik karena memang guru tidak didesain untuk menjadi guru seni yang mempunyai kemampuan dibidang seni seperti seni tari, seni musik ataupun seni rupa.

Selain dari segi materi guru juga menemui tantangan dalam hal waktu dan media. Seni Budaya dan Prakarya (SBdP) merupakan muatan pelajaran yang lebih mengutamakan praktik daripada teori sehingga membutuhkan waktu yang tidak sedikit sementara jika mengacu pada RPP waktu yang tersedia jika harus mengajarkan teori dan ditambah lagi dengan praktik watunya masih kurang. Kemudian pada saat praktik tentunya membutuhkan media, di beberapa sekolah seringkali guru kesulitan mencari media ketika akan melaksanakan praktik dan mau tidak mau guru harus membawa sendiri media berupa peralatan untuk praktik dari rumah dan begitupun dengan siswa yang harus membawa beberapa barang dari rumah agar praktik tetap bisa berjalan dengan lancar.

Seni Budaya dan Prakarya mempunyai peran yang sangat besar bagi siswa, karena materi pokok dalam Seni Budaya dan Prakarya mengandung beberapa sifat yang penting, seperti multidimensional, multilingual, dan multikultural. Multidimensional berarti seni mampu mengembangkan berbagai jenis kecerdasan manusia, seperti kecerdasan emosi, kecerdasan intelektual, kecerdasan kreatif, kecerdasan moral serta kecerdasan spiritual. Melalui berbagai peningkatan kecerdasan tersebut diharapkan mampu membentuk karakter yang kuat sehingga siap dalam mengikuti pembelajaran. Pendidikan seni juga mampu menjadikan siswa inovatif, kritis, kreatif, imajinatif, dan mengembangkan kepekaan sosial dalam lingkungannya.

Multilingual berarti mengembangkan kemampuan berkomunikasi melalui berbagai ragam bahasa, seperti bahasa dalam hal ini digunakan untuk berkomunikasi secara visual, bunyi, dan gerak. Sifat multikultural berarti melalui seni budaya dan prakarya mampu memupuk rasa persaudaraan dan saling menghargai antar sesama manusia serta menumbuhkan rasa bangga terhadap budaya sendiri maupun budaya orang lain. Sehingga seni dapat dijadikan sebagai dasar pemersatu bangsa (Prawira, 2016).

Keberadaan karya seni secara teoritis mempunyai tiga macam fungsi, yaitu fungsi personal (mengekspresikan karya seni dilihat dari pandangan personal penciptanya, contoh: karya patung yang dibuat untuk menggambarkan kebesaran cintanya Frans Hall), fungsi sosial (kecederungan untuk mempengaruhi tingkah laku terhadap kelompok manusia, contoh: poster dan reklame), dan fungsi fisik (berorientasi pada kebutuhan fisik, contoh: sendok, dekorasi, busana, dan perabot rumah tangga) (Kartika, 2017). Diantara fungsi dan tujuan Seni Budaya dan Prakarya yaitu pengembangan sikap, keahlian, dan antusias dalam berkarya sehingga menciptakan generasi-generasi yang kreatif serta mampu berpikir kritis dalam menghadapi era digital ini (Susanto, 2013). 
Beberapa aspek dalam materi pokok Seni Budaya dan Prakarya adalah sebagai berikut: seni rupa, seni musik, dan seni tari (Bahari, 2014).

1) Tantangan Mengajarkan Muatan seni Rupa

Seni rupa merupakan wujud hasil karya manusia yang diterima melalui indera penglihatan, secara garis besar dibagi menjadi seni murni dan seni terap. Seni murni merupakan istilah untuk mencirikan bahwa karya sastra yang dihasilkan tidak bermaksud untuk memenuhi tujuan praktis, tetapi murni sebagai media ekspresi seperti seni lukis, seni patung, dan seni grafis. Sedangkan seni terap adalah seni yang digunakan untuk kebutuhan sehari hari, seperti pakaian dan peralatan dapur (Bahari, 2014).

Beberapa tatangan yang dialami oleh guru yaitu kurangnya media untuk mendukung pembelajaran seni rupa terutama pada saat kegiatan praktik. Seringkali siswa dan guru harus mencari media secara mandiri dan kadang ada alat ataupun bahan yang sulit untuk di cari di lingkungan sekitar kecamatan Kembaran Kabupaten Banyumas.

2) Tantangan Mengajarkan Muatan Seni Musik

Seni musik adalah seni yang diterima melalui indera pendengaran. Secara garis besar, musik dibagi mejadi dua yaitu diatonis dan pentatonis. Contoh musik diatonis adalah piano, gitar, ansambel, dan orkesta. Contoh musik pentatonis adalah gamelan (Bahari, 2014).

Beberapa tantangan yang dihadapi oleh guru pada saat mengajarkan muatan pelajaran seni terutama dalam bidang seni musik yaitu teori yang terdapat didalam modul masih sulit ntuk dipahami baik itu oleh siswa maupun guru. Selain itu materi juga dianggap terlalu tinggi bagi siswa sekolah dasar seharusnya materi yang diajarkan di sekolah dasar jangan yang terlalu tinggi hal ini yang membuat pembelajaran menjadi terhambat baik saat pembelajaran teori ataupun praktik. Selain itu masih sedikit guru yang menguasai dan paham mengenai alat musik, hanya ada sdikit guru yang bisa mempraktikkan dan memainkan alat musik dengan baik.

3) Tantangan Mengajarkan Muatan Seni Tari

Seni tari adalah seni yang dapat dilihat melalui indera penglihatan dan dapat dinikmati melalui gerakan-gerakan tubuh dengan ritme yang teratur dan diiringi musik. Seni tari meliputi keterampilan gerak dengan memadukan antara audio, tari, dan rasa serta apresiasi terhadap tariantarian (Bahari 2014).

Beberapa tantangan yang dialami leh gutu pada saat mengajarkan muatan SBdP terutama dibidang seni tari kebanyakan dari guru laki - laki, walaupun tidak semua partisipan guru laki - laki merasa kesulitan tetapi memang kebanyakan guru laki - laki mengalami kesulitan pada saat kegiatan praktik karena memang sebelumnya guru tidak mempunyai basic 
di bidang seni apalagi seni tari sehingga guru masih kaku ketika mempraktikkannya. Pada saat materi tentang tari - tari tradisional dimana guru harus mempraktikkannya seringkali guru kesulitan dalam mempraktikkannya

\subsection{Faktor yang Mempengaruhi Kinerja Guru}

Menurut Ahmad Susanto (2016:73) terdapat beberapa faktor yang mempengaruhi terbangunnya suatu kinerja guru antara lain:

a. Faktor internal

Faktor internal adalah faktor yang mempengaruhi seseorang yang berasal dari dalam diri. Contohnya, kepercayaan menjadi pandangan hidup seseorang guru.

b. Faktor eksternal

Faktor eksternal adalah faktor yang mempengaruhi seseorang yang berasal dari luar diri. Contohnya, volume upah kerja yang dapat memenuhi kebutuhan seseorang.

Dapat disimpulkan bahwa Faktor yang cukup mencolok yaitu faktor eksternal, dimana faktor eksternal yaitu faktor yang mempengaruhi seseorang yang berasal dari luar diri. Faktor yang mempengaruhi kinerja guru dalam mengajarkan muatan pelajaran SBdP kurikulum 2013 di Sd wilayah Kecamatan Kembaran yaitu dari latar belakang pendidikan guru contohnya guru dengan riwayat pendidikan S1 kinerjanya lebih baik dibandingkan dengan guru dengan riwayat pendidikan UT. Kemudian yang kedua adalah faktor usia, tentunya performa dari guru akan menurun seiring dengan bertambahnya usia guru - guru senior jika dibandingkan dengan guru - guru muda tentunya akan kalah atau guru dengan usia yang lebih muda cenderung mempunyai kinerja yang lebih baik jika dibandingkan dengan guru yang sudah senior kemudian yang terakhir yaitu status kepegawaian, berdasarkan hasil wawancara dan observasi tidak bisa dipungkiri bahwa kinerja guru dengan status Pegawai Negeri Sipil jauh lebih baik jika dibandingkan dengan gueu wiyata bakti.

\section{Kesimpulan}

Berdasarkan hasil penelitian dapat disimpulkan bahwa masih banyak ditemui tantangan dalam dalam mengajarkan muatan SBdP di SD wilayah Kecamatan Kmbaran seperti beberapa diantaranya yaitu dari materi yang dianggap terlalu tinggi sehingga guru dan siswa kerap kali kesulitan untuk memahami materi yang disampaikan hal tersebut dikarenakan guru yang memang tidak mempunyai basic dibidang seni. selain itu materi yang termuat didalam modul baik itu buku guru ataupun buku siswa masih sangat kurang sehingga guru haru mencari reverensi materi dari sumber lain baik itu dari buku ataupun internet. Selain dari segi materi 
guru juga kerap kali terkendala dalam hal media serta sarana dan prasarana pendukung, seringkali guru dan siswa bahu membahu saling bererjasama membawa media yang dibutuhkan untuk kegiatan praktik agar pembelajaraan bisa berjalan dengan lancar.

Saran yang dapat saya berikan yaitu guru diharapkan bisa memberikan pembelajaran SBdP yang menyenangkan bagi siswa yaitu dengan cara memadukan antara teori dan praktik pada saat pembelajaran jangan hanya terfokus dengan teori saja selain itu sebelum proses pembelajaran guru mempelajari terlebih dahulu materi yang akan disampaikan terutama untuk materi yang belum terlalu dikuasai oleh guru, guru bisa mencari dari reverensi lain selain dari modul dan bagi sekolah sebaiknya menyediakan sarana dan prasarana yang memadai untuk kegiatan praktik agar kinerja guru bisa maksimal.

\section{DAFTAR PUSTAKA}

A.A. Anwar Prabu Mangkunegara ,2000, Manajemen Sumber Daya Manusia, Bandung. PT, Remaja Rosdakarya.

Ahmad, Susanto. (2013). Teori Belajar dan Pembelajaran di Sekolah Dasar. Jakarta: Prenadamedia Group.

Aminuddin. 2009. Pengantar Apresiasi Puisi Karya Sastra. Bandung: Sinar Baru Algensindo.

Ansori, I. 2015. "Persepsi Guru Dalam Implementasi Kurikulum 2013 di Sekolah Dasar Negeri Kauman 07 Batang Tahun Pelajaran 2014/2015". Skripsi. Surakarta: Universitas Muhammadiyah Surakarta.

Bahari, Nooryan. 2014. KRITIK SENI Wacana, Apresiasi dan Kreasi.Yogyakarta: Pustaka Pelajar.

Batahai, F. 2015. "Persepsi Guru Terhadap Penerapan Kurikulum 2013 di SDN Se-Kecamatan Kabila, Kabupaten Bone Bolango”. Skripsi. Gorontalo: Universitas Negeri Gorontalo.

Dharsono (Sony Kartika). 2017. Seni Rupa Modern. Bandung: Rekayasa Sains.

Malik, Muh Syauqi. (2020). Analisis HOTS, 4 Cliterasi, dan Pendidkan Karakter Dalam Seni Budaya dan Prakarya MI/SD Kurikulum 2013, 8 (2), 63-66.

Maria, M., Shahbodin, F., \& Pee, N. C. (2016). Malaysian higher education system toward industry 4.0 - Current trends overview. Proceeding of the 3 rd International Conference on Applied Science and Technology (AIP Publishing), 1-7.

Permendikbud No 16 tahun 2007 tentang standar Kualifikasi akademik dan Kompetensi Guru diakses melalui http://vervalsp.data.kemdikbud.go.id/prosespembelajaran/file/Permendiknas $\% 20 \mathrm{No} \% 20$ 16\%20Tahun\%202007.pdf 
Permendikbud No 20 tahun 2003 tentang Sistem Pendidikan Nasional diakses melalui https://pusdiklat.perpusnas.go.id/public/media/regulasi/2019/11/12/2019_11_12$03 \quad 49 \quad 06 \quad 9 a b 7 e 1$ fa524ba603bc2cdbeb7bff93c3.pdf

Permendikbud No 65 tahun 2013 tentang Standar Proses Pendidikan Dasar dan Menengah diakses melalui https://bsnp-indonesia.org/wp-content/uploads/2009/06/03.-A.-SalinanPermendikbud No.-65-th-2013-ttg-Standar-Proses.pdf

Primadi Tabrani. 2009. Peran Pendidikan Seni dalam Pendidikan Integral. Jakarta: FF the Foundation-UPI.

Puskur. (2007).Kajian Kebijakan Kurikulum Keterampilan.Dekdikbud.

Ridwan. (2016). Pembejaran Seni Musik tematik Sebagai Implementasi Kurikulum 2013, 2 (2), 18-29.

Salam, Sofyan. 2000. "Program Muatan Lokal Sebagai Upaya Revitalisasi Seni Rupa Tradisional". Makalah Disajikan Dalam Seminar Revitalisasi Seni Rupa Tradisional.2228 Februari 2000. UNM Makasar. Salam, Sofyan. 2001. Pendidikan Seni Rupa di Sekolah Dasar. Makasar: Universitas Negeri Makasar.

Sugiyono. (2015). Metode Penelitian: Pendekatan Kuantitatif, kualitatif, dan $R \&$ D. Bandung. Alfabeta.

Sugiyono. (2017). Metode Penelitian Kombinasi (Mixed Methods), Bandung: Alfabeta.

Sumanto. 2006. Pengembangan Kreativitas Seni Rupa Anak TK. Jakarta: Direktorat Jendral Pendidikan Tinggi Direktorat Pendidikan Tenaga Kependidikan Dan Tenaga Perguruan Tinggi.

Undang Undang No 20 tahun 2003 tentang Sistem Pendidikan Nasional diakses melaui https://jdih.kemenkeu.go.id/fulltext/2005/14tahun2005uu.htm\#: :text=Dalam\%20Undan g\%2DUndang\%20ini\%20yang,2.

Wibawa, S. (2018). Pendidikan dalam Era Revolusi Industri 4.0. Indonesia. "Guru Era 4.0", http://krjogja.com/web/news/read/59981/Guru_Era_4_0, diakses November 2019. 